\title{
KADENCJA CZŁONKÓW ZARZĄDU SPÓŁKI Z 0.0.
}

\section{Wprowadzenie}

Przepisy kodeksu spółek handlowych ${ }^{2}$ dotyczące zarządu spółki z o.o. czas pełnienia funkcji członka tego organu określaja, odwołując się do pojęcia „mandat” (art. 202 ksh.). Ściślej, wskazują dzień wygaśnięcia mandatu, nie stanowiąc wprost o tym, od kiedy mandat członkowi zarządu przysługuje. W praktyce większe znaczenie przywiązuje się do pojęcia „,kadencja”. Nie budzi wątpliwości, że członkostwo w zarządzie spółki z o.o. może być dość swobodnie ograniczone co do ram czasowych przez odwołanie się w umowie spółki właśnie do pojęcia kadencji i określenia czasu jej trwania.

Kodeks spółek handlowych używa pojęcia ,kadencja członka zarządu spółki z o.o." tylko w kontekście ustalenia, że dopuszczalne jest powołanie członków zarządu na okres wspólnej kadencji (art. $202 \S 3 \mathrm{ksh}$.). Daje to podstawę do ustalenia, że „wspólna kadencja” charakteryzuje się równoczesnością wygasania mandatów wszystkich członków zarządu, chociaż poszczególni członkowie zarządu mogli uzyskać mandat w różnym czasie. Trudno jednak w oparciu o przepis art. $202 \S 3 \mathrm{ksh}$. sformułować ogólne pojęcie kadencji członka zarządu spółki z o.o. Nie zostało ono w przepisach ksh. zdefiniowane. Co więcej, nie jest jasne, czy okres sprawowania funkcji przez członków zarządu spółki z o.o. można określić mianem „kadencja”, czy też ustawowo termin ten zastrzeżony jest jedynie dla członków zarządu spółki akcyjnej ${ }^{3}$ z uwagi na art. $369 \S 1 \mathrm{ksh}$. wyznaczający zakres tego pojęcia tylko w odniesieniu do zarządu spółki akcyjnej. Brak jest analogicznej regulacji w odniesieniu do zarządu spółki z o.o.

Dr Elżbieta Bieniek-Koronkiewicz - autor punktów 1, 2, 5, 6, mgr Marek Zaremba - autor punktów 3, 4, 5, 6. Ustawa z 15 września 2000 r. Kodeks spółek handlowych, Dz.U. Nr 94, poz. 1037 z późn. zm., dalej cyt. jako ksh.

3 Por. A. Gburzyńska-Dulewicz, Pozycja prawna zarządu i członków zarządu spółek kapitałowych, Warszawa 2006, s. 138. 
Doktryna wielokrotnie podejmowała temat kadencji członków organów spółki $\mathrm{z}$ o.o., zwłaszcza w zestawieniu z pojęciem mandatu ${ }^{4}$. W istocie na gruncie przepisów dotyczących spółek handlowych nie sposób mówić o kadencji bez odwoływania się do pojęcia mandatu. Zdaniem A. Kidyby ${ }^{5}$ nie ma powodu, aby przeciwstawiać sobie te dwa terminy. Generalnie pojęcie mandatu i kadencji stanowią aspekty tego samego zjawiska, jakim jest pełnienie obowiązków i wykonywanie praw członka zarządu. Problem w tym, że brak jest jednoznacznej definicji obu tych pojęć. Ustawodawca nie przesądził ani zakresu pojęć mandat i kadencja, ani też relacji, jaka między nimi zachodzi. W dyskusji dotyczącej tej relacji wyrażono też pogląd, że upływ kadencji jest równoznaczny z pozbawieniem funkcji członka zarządu jako piastuna organu, ale nie prowadzi to do automatycznego wygaśnięcia mandatu 6 . Pogląd ten akcentuje różnicę pomiędzy okresem pełnienia przez członka organu zarządzającego jego funkcji a sprawowaniem przez niego mandatu, przyjmując, że nie musi to być ten sam okres ${ }^{7}$. Dodatkowo problem komplikuje się wobec dyskusyjnego charakteru prawnego członkostwa w organach spółki ${ }^{8}$.

Kodeks handlowy ${ }^{9}$ stanowił w art. 196, iż mandaty członków zarządu wygasają z dniem odbycia zgromadzenia wspólników, zatwierdzającego sprawozdanie, bilans i rachunek zysków i strat za ostatni rok ich urzędowania. Aktualnie obowiązujące przepisy kodeksu spółek handlowych, tj. art. $202 \S 1,2$ i 4 ksh., przejmując tę samą zasadę wygasania mandatu $z$ dniem odbycia zgromadzenia wspólników zatwierdzającego sprawozdanie finansowe za pierwszy bądź ostatni rok obrotowy pełnienia funkcji, doprecyzowują trzy istotne kwestie: 1) chodzi o pełny rok obrotowy (pierwszy i jedyny, gdy członka zarządu powołano na okres nie dłuższy niż rok lub ostatni rok pełnienia funkcji w przypadku powołania członka zarządu na okres dłuższy niż rok), 2) umowa spółki może stanowić inaczej, 3) śmierć, rezygnacja oraz odwołanie ze składu zarządu skutkuje wygaśnięciem mandatu ${ }^{10}$.

W latach 90-tych ubiegłego wieku, jeszcze pod rządami kodeksu handlowego, temat ten podjęli jako pierwsi J.Brol i M Safjan, Mandat a kadencja członka zarządu spółki z o.o. (art. 196 kh), PPH 1995, nr 11, s. 1. Inne ważniejsze publikacje z tego okresu: J. Krauss, Komentarz do postanowienia SW z dnia 6 marca, 1996 r XX GR 194/95, PPH 1996, nr 8, s. 38; S. Sołtysiński, A. Nowicka, Okres urzędowania a czas trwania mandatu członków zarządu spółek kapitałowych, PPH 1998, nr 5, s. 5; Z. Kuniewicz, Chwila wygaśnięcia mandatu pochodzącego z wyboru członka organu spółki kapitałowej, PS 1998, nr 3, s. 38; W. Jurcewicz, Kadencja zarządu w spółce akcyjnej, PPH 1999, nr 4, s. 38; J. Trzebiński, Mandat a członkostwo we władzach spółek kapitałowych, PPH 1999, nr 12, s. 29. Po wejściu w życie ksh. na ten temat pisali m.in. A. Opalski, Kadencja i mandat członka zarządu, PPH 2003, nr 10, s. 38; W. Popiołek, Wygaśnięcie mandatu członka organu spółki kapitałowej - zagadnienia wybrane, (w:) Kodeks spółek handlowych po pięciu latach, Wrocław 2006, s.781; A. Szumański, Przesłanka wygaśnięcia mandatu członka zarządu spółki kapitałowej w trybie art. 202 § 2 albo art. 369 § 4 ksh., „Prawo Spółek” 2007, nr 2, s. 2; P. Pinior, Wygaśnięcie mandatu członka zarządu spółki kapitałowej, „Prawo Spółek” 2008, nr 78, s. 2.

$5 \quad$ A. Kidyba, Kodeks spółek handlowych. Komentarz. T. I, Warszawa 2008, s. 822.

6 J. Brol, M. Safjan, op. cit., s. 3.

$7 \quad$ I CKN 1279/00, LEX nr 74506.

8 Szerzej E. Płonka, Mechanizm łączenia skutków działań prawnych z osobami prawnymi na przykładzie spółek kapitałowych, Wrocław 1994; E. Płonka, Umocowanie zarządu spółki kapitałowej do jej reprezentacji, NP 1990, nr 4-6, s. 3 i nast.

9 Rozporządzenie Prezydenta RP z 27 czerwca 1934 r., Dz.U. Nr 57, poz. 502 z późn. zm.

10 D. Wajda, Rezygnacja z członkowstwa w zarządzie spółki kapitałowej, „Prawo Spółek” 2008, nr 6, s. 23. 
Kodeks spółek handlowych przesądził jednoznacznie pewne kwestie związane $\mathrm{z}$ podniesioną problematyką, które były sporne na gruncie kh. W szczególności przeciął dyskusję co do problemu chwili wygaśnięcia mandatów osób odwołanych ze składu zarządu, składających rezygnację oraz zmarłych członków zarządu, stanowiąc w art. $202 \S 4 \mathrm{ksh}$., że zdarzenia te skutkują wygaśnięciem mandatu. Jednak dalej nie daje jasnej odpowiedzi na pytania dotyczące w szczególności: jak liczyć czas kadencji (lata kalendarzowe, lata obrotowe), czy kadencja ulega wydłużeniu (a może w niektórych sytuacjach skróceniu) do czasu wygaśnięcia mandatu, czy też kadencja się kończy, ale nie kończy się czas posiadania mandatu, a jeżeli tak, to czy sytuacja członka zarządu, którego kadencja jeszcze nie upłynęła, różni się od sytuacji tego, którego kadencja upłynęła, ale mandat jeszcze nie wygasł. Pytania te mają nie tylko walor teoretyczny, porządkujący. Mają one bezpośrednie odniesienie do praktyki, ponieważ podniesione wątpliwości mogą być podstawą do kwestionowania ważności czynności dokonanych przez członków zarządu.

Kompleksowa analiza wszystkich zagadnień składających się na problem ram czasowych pełnienia funkcji w zarządzie spółki z o.o. nie jest możliwa w ramach tego opracowania. Autorzy za cel stawiają sobie wyjaśnienie tylko tych kwestii, które pozwolą zaproponować spójną koncepcję liczenia czasu pełnienia funkcji w zarządzie spółki z o.o., dającą zastosować się w praktyce, jeżeli w umowie spółki zamieszczono klauzulę wskazującą, że członków zarządu powołuje się na określoną liczbę lat, najczęściej sformułowaną przez odwołanie się do pojęcia kadencja (np. "Członków zarządu powołuje się na 3-letnią kadencję".). Mając na uwadze ten cel konieczne jest ustalenie desygnatu pojęcia „kadencja” w ścisłym powiązaniu z kodeksowym pojęciem ,mandat”.

\section{Mandat a kadencja na gruncie przepisów kodeksu spółek handlowych}

Słowo „mandat” pochodzi od łacińskiego mandatum. W prawie rzymskim był to termin określający umowę - odpowiednik dzisiejszego zlecenia. Od czasów rzymskich znaczenie pojęcia „mandat” ewoluowało, przyjmując w różnych systemach prawnych zbliżone, chociaż nie zawsze takie samo znaczenie. Przykładowo $\mathrm{w}$ ustawodawstwie francuskim oznacza generalnie zlecenie lub pełnomocnictwo ${ }^{11}$. We francuskim prawie spółek podkreśla się, że mandat powstaje w momencie formalnego powołania, a czas trwania mandatu pokrywa się z czasem urzędowania ${ }^{12}$.

Przedstawiciele polskiej doktryny na ogół, wyjaśniając pojęcie mandat, odwołują się do etymologii tego słowa. W wyniku takiego podejścia przyjmuje się, 
że mandat stanowi upoważnienie do pełnienia obowiązów i wykonywania praw członka zarządu. Jest uprawnieniem do sprawowania funkcji piastuna organu osoby prawnej ${ }^{13}$. Rozumiany też jest jako suma obowiązków członka zarządu ${ }^{14}$. Upoważnienie i odpowiadający mu obowiązek nieodzownie związane są z powołaniem w skład organu spółki, jako osoby prawnej. Na tle tak zdefiniowanego pojęcia mandat należy przypomnieć inny pogląd, według którego mandat to pewna formalna relacja istniejąca pomiędzy członkiem zarządu (również nie urzędującym) a spółką do czasu udzielenia skwitowania ${ }^{15}$. W podobnym stanowisku mandat utożsamiano z zobowiązaniem, które wynika ze stosunku organizacyjnego członka zarządu, a nie $\mathrm{z}$ formalnym członkostwem w zarządzie ${ }^{16}$. Stanowisko to znalazło odzwierciedlenie w powołanym wyżej wyroku SN z 6 listopada 2002 r., który zapadł jeszcze na gruncie przepisów kodeksu handlowego. Sąd Najwyższy przyjął, że konieczne jest odróżnienie urzędowania członka zarządu, czyli piastuna organu osoby prawnej, od mandatu członka zarządu. Według tego stanowiska mandat członka zarządu przysługuje zarówno urzędującemu członkowi zarządu, jak również członkowi zarządu, który utracił atrybut członka urzędującego wskutek upływu czasu, na jaki został powołany (kadencja). W związku z tym stanowiskiem podnoszono, iż wynika z niego rozróżnienie dwóch kategorii członków zarządu: urzędujących i nieurzędujących, z których każda posiada ważny mandat. Według krytyków tego poglądu rodzi to zasadniczy problem, zwłaszcza wobec niesprecyzowanych uprawnień i obowiązków nieurzędujących członków zarządu

Co do pojęcia „kadencja” w doktrynie zwykle przyjmuje się, iż kadencja wyznacza okres pełnienia funkcji ${ }^{17} \mathrm{i}$ jest to okres sprawowania funkcji przez członka zarządu ${ }^{18}$. Pogląd ten wyraźnie koresponduje z treścią art. $369 \S 1$ ksh., który w odniesieniu do członkostwa w zarządzie spółki akcyjnej stanowi, że okres sprawowania funkcji przez członka zarządu nie może być dłuższy niż pięć lat (kadencja). Rozciągnięcie wprost definicji z art. $369 \S 1 \mathrm{ksh}$. na grunt spółki z o.o. wydaje się nieuzasadnione. Brak odpowiednika powołanego przepisu w regulacji zarządu spółki z o.o. może sugerować niedopatrzenie ustawodawcy, jednakże bliższa analiza tego założenia nie potwierdza. Wprowadzenie pojęcia „kadencja” do art. $369 \S 1$ $\mathrm{ksh}$. miało na celu tylko i wyłącznie ograniczenie czasu sprawowania funkcji w zarządzie spółki akcyjnej do 5 lat i tym samym wyłączenie możliwości powoływania członków zarządu na czas dłuższy, a zwłaszcza nieoznaczony. Powód ten odpada w przypadku zarządu spółki z o.o., gdzie takich ograniczeń nie wprowadzono. Sko-

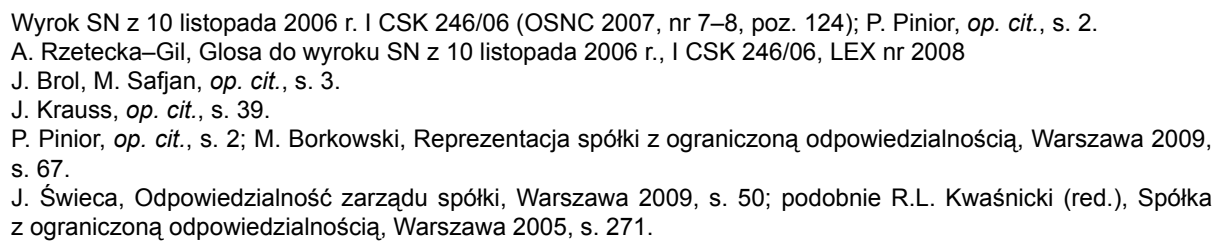


ro tak, to posługiwanie się definicją kadencji skonstruowaną w innym celu nie wydaje się prawidłowe.

Ponadto, czy słuszne jest rozumienie kadencji jako okresu sprawowania funkcji w zarządzie spółki, skoro ustawowo ten czas kończy się z chwilą wygaśnięcia mandatu, a nie z chwilą upływu kadencji. Ustalenie kadencji rocznej lub wieloletniej w żadnym wypadku (niezależnie od sposobu jej liczenia, co budzi zasadnicze kontrowersje i o czym dalej jest mowa) nie oznacza, że dany członek zarządu będzie pełnił funkcję dokładnie przez rok lub tyle lat, na ile wyznaczono kadencję. Będzie ją pełnił do czasu wygaśnięcia mandatu. Dokładnej daty tego zdarzenia z zasady się nie ustala. Pomijając sytuacje, których z istoty rzeczy nie da się ściśle przewidzieć, a które skutkuja, jak stanowi art. $202 \S 4$ ksh., wygaśnięciem mandatu (śmierć członka zarządu, jego rezygnacja lub odwołanie z funkcji), mandat wygasa z dniem odbycia zgromadzenia wspólników zatwierdzającego sprawozdanie za pierwszy (art. $202 \S 1 \mathrm{ksh}$.) lub ostatni (art. $202 \S 2 \mathrm{ksh}$.) rok obrotowy pełnienia funkcji członka zarządu. Stosownie do art. $231 \S 1 \mathrm{ksh}$. data, w której odbędzie się takie zgromadzenie, może przypaść na każdy z dni w ciągu 6 miesięcy po zakończeniu roku obrotowego, w zależności od decyzji organu zwołującego zwyczajne zgromadzenie wspólników (z zasady zarządu). Zatem, co do zasady, nie można ustalić dokładnego czasu pełnienia funkcji w zarządzie z tego powodu, że nie da się ustalić z góry daty wygaśnięcia mandatu. W żadnym też razie kadencja wyznaczana w latach nie oznacza czasu sprawowania funkcji. Jak wskazują niżej prezentowane przykłady, nie można nawet powiedzieć, że kadencja w przybliżeniu wyznacza ten czas, skoro faktyczne pełnienie funkcji może być wydłużone nie tylko o dni czy miesiące, ale nawet lata.

Jeśli więc uznać za potrzebne posługiwanie się pojęciem kadencja, obok pojęcia „posiadania” czy „sprawowania” mandatu należy je definiować nie jako czas pełnienia funkcji, lecz okres, na jaki powoływani są członkowie zarządu ${ }^{19}$. Członkowie zarządu powołani mogą być na np. 2 lata (2-letnia kadencja), a pełnić funkcję będą od momentu powołania do czasu wygaśnięcia ich mandatów. Czas pełnienia funkcji rozpoczyna się w momencie powołania, przy założeniu przyjęcia funkcji. Jest to jednocześnie początek kadencji oraz moment, od którego członek zarządu posiada mandat do pełnienia funkcji. Zatem data powołania, początku kadencji i początku pełnienia mandatu jest wspólna. Rozpoczęcie kadencji pokrywa się z uzyskaniem mandatu ${ }^{20}$. Powstaje natomiast pytanie, czy analogicznie wspólna jest data końcowa. 
W tej kwestii poglądy są różne. Przyjęcie do obliczania kadencji zasady wynikającej z art. 112 kc. ${ }^{21}$, który stanowi, że termin oznaczony w latach kończy się z upływem dnia, który datą odpowiada początkowemu dniowi terminu, wydaje się uzasadnione. Wszak długość kadencji podawana jest z zasady w latach. Zatem kadencja upływa z końcem dnia odpowiadającego dacie jej początku, po upływie odpowiedniej liczby lat. Powstaje pytanie, czy ulega ona przedłużeniu (skróceniu) tak, że jej koniec następuje w chwili wygaśnięcia mandatu? Wątłą podstawą pozytywnej odpowiedzi jest powoływanie się na przepisy o wygasaniu mandatów, ponieważ one nie odnoszą się do kadencji. Może więc należy przyjąć, że wprawdzie kadencja kończy się, ale nie wygasają mandaty. Zatem czas pełnienia funkcji dokładnie pokrywa się z czasem pełnienia mandatu (i co do początku i co do końca), jednak nie dotyczy to kadencji.

Przeciwny pogląd zakłada, że nigdy nie powstanie sytuacja utrzymywania się

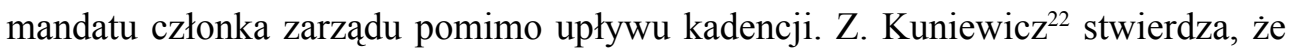
wynika to z wyłączenia stosowania art. $112 \mathrm{kc}$. do obliczania kadencji. Podstawą wyłączenia tego przepisu może być art. 110 kc., który dopuszcza stosowanie innej reguły, gdy określa ją ustawa, orzeczenie sądu lub decyzja innego organu państwowego albo czynność prawna. Powołany autor przyjmuje, że kodeks spółek handlowych jest właśnie ustawą określającą sposób obliczania kadencji członka zarządu, a zatem wyłącza stosowanie reguły wynikającej z art. 112 kc. Jednakże żaden z przepisów ksh. nie określa sposobu obliczania kadencji członka zarządu spółki z o.o. Wbrew przytoczonemu poglądowi nie czyni tego art. $202 \mathrm{ksh}$. Przepis ten określa tylko z jakim zdarzeniem wiązać należy wygaśnięcie mandatu członka zarządu. Zasady określone w art. 202 ksh. mają zastosowanie także wtedy, gdy umowa spółki nie sprecyzuje czasu, na jaki członek zarządu został powołany, a więc nie wyznacza długości kadencji.

Wyłączenie stosowania art. 112 kc. do obliczania kadencji członków zarządu spółki z o.o. jest także podstawą poglądu, według którego kadencję oblicza się według pełnych lat obrotowych ${ }^{23}$. Uzasadnieniem tego poglądu jest zasada wynikająca z ksh., że członek zarządu zawsze ,rozlicza się” ze spółką z tytułu pełnienia funkcji w danym roku obrotowym. Zdaniem W. Popiołka ${ }^{24}$ tej zasadzie odpowiada rozwiązanie, które wiąże pojęcie okresu kadencji (kolejnych jej lat) z kolejnymi latami obrotowymi, co pozostaje w zgodzie z ,rytmem funkcjonowania” spółki kapitałowej. Akceptacja tego poglądu rodzi jednak pewne wątpliwości.

\footnotetext{
21 Ustawa z dnia 23 kwietnia 1964 r. Kodeks cywilny, Dz.U. Nr 16, poz. 93 ze zm., dalej cyt. jako kc.

22 Z. Kuniewicz, Uwagi o kadencyjności pełnienia funkcji w zarządzie spółki kapitałowej, (w:) Kodeks spółek handlowych po pięciu latach, Wrocław 2006, s. 713.

23 W. Popiołek, op. cit., s. 782.

24 Ibidem, s. 784.
} 
Przede wszystkim obliczanie kadencji według pełnych lat obrotowych powinno oznaczać, że kadencja kończy się wraz z końcem pełnego roku obrotowego (pierwszego w przypadku przewidzianym w art. $202 \S 1 \mathrm{ksh}$. lub ostatniego w sytuacji, o której mowa w art. $202 \S 2 \mathrm{ksh}$ ). Jej przedłużenie do dnia zatwierdzenia sprawozdania finansowego za ten rok $^{25}$ jest w tej koncepcji słabo uzasadnione. Oznacza przecież, że na okres kadencji składają się oprócz pełnych lat obrotowych jeszcze okresy stanowiące część roku obrotowego, z których członek zarządu również musi się ,rozliczyć”. Z okresu niepełnego roku obrotowego związanego z początkiem kadencji „rozliczy” się na zwyczajnym zgromadzeniu w swoim pierwszym pełnym roku pełnienia funkcji. W art. $231 \S 3 \mathrm{ksh}$. wyraźnie jest mowa o tym, że kwestia udzielenia absolutorium (a więc „rozliczenia”) dotyczy wszystkich osób, które pełniły funkcję członków zarządu w ostatnim roku obrotowym. Rozliczany więc będzie poprzednik (poprzednicy) i następca, pełniący funkcję w danym roku. Analogiczna sytuacja będzie miała miejsce po upływie ostatniego pełnego roku obrotowego pełnienia funkcji kolejnego członka zarządu. Na zwyczajnym zgromadzeniu członek zarządu jest „rozliczany” za rok obrotowy, który się zakończył. Następuje to zwykle kilka miesięcy po zakończeniu roku obrotowego. Jeżeli nawet przyjąć, że kadencja kończy się dopiero wówczas, gdy wygasa mandat, nadal istnieje problem „rozliczenia” za część bieżącego roku obrotowego, co nastąpi dopiero w kolejnym roku. Dotyczy to takich sytuacji, gdy dana osoba pełniła funkcję przez część roku obrotowego, a w jego trakcie jej mandat wygasł. Tak będzie nie tylko wskutek zdarzeń, o których mowa w art. $202 \S 4$ ksh. (odwołanie, rezygnacja, śmierć), ale także w zwykłym toku rzeczy, gdy mandaty wygasają z dniem określonym w art. $202 \S 1$ i $2 \mathrm{ksh}$. Jeżeli dany członek zarządu nie zostanie powołany w skład zarządu ponownie, to oczywiście jego funkcja ustaje, ale na kolejnym zwyczajnym zgromadzeniu wspólników stanie problem udzielenia mu absolutorium za tę cześć roku obrotowego, w której pełnił funkcję. W konsekwencji koncepcja opierająca się na założeniu, że kadencja obliczana ma być według lat obrotowych, ponieważ tak są „,rozliczani” członkowie zarządu, nie wydaje się przekonywująca. Nie rozwiązuje bowiem zasadniczego problemu, a mianowicie nie wyjaśnia dlaczego należy przyjać, że tak obliczana kadencja skończy się z dniem odbycia zgromadzenia zatwierdzającego sprawozdanie finansowe.

Podobnie nie daje satysfakcjonującego rozwiązania koncepcja liczenia lat obrotowych kadencji odrębnych od lat obrotowych spółki ${ }^{26}$. Zakłada ona, że rok obrotowy pełnienia funkcji członka zarządu nie musi pokrywać się z rokiem obrotowym samej spółki. Przyjmuje, że pozostając w zgodzie z przepisami ustawy o rachunkowości, przez rok obrotowy pełnienia funkcji członka zarządu należy rozumieć okres dwunastu kolejnych pełnych miesięcy, który nie musi pokrywać się z rokiem kalen-

26 A. Gburzyńska-Dulewicz, op. cit., s. 140. 
darzowym i nie musi być tożsamy z rokiem obrotowym samej spółki. Autorka tej koncepcji, A. Gburzyńska ${ }^{27}$, z powyższych założeń wywodzi wniosek, że mandat członka zarządu wygasa z dniem odbycia zgromadzenia, o którym mowa w art. 202 $\S 1$ ksh., jeżeli odbywa się ono co najmniej po upływie dwunastu miesięcy od momentu powołania do składu organu. Nie wydaje się jednak, aby stanowisko to dawało inne rezultaty niż liczenie kadencji według lat kalendarzowych. Co najwyżej godzi takie liczenie z użytym w art. 202 pojęciem roku obrotowego. Nie wyjaśnia natomiast, dlaczego upływ kolejnych dwunastu miesięcy (,roku obrotowego pełnienia funkcji”) nie kończy okresu sprawowania funkcji (skoro kadencja wynosi rok), lecz ulega automatycznemu przedłużeniu do najbliższego zgromadzenia zatwierdzającego sprawozdanie finansowe. Jednak zdecydowanie łatwiej zaakceptować tę koncepcję niż nakazującą liczenie kadencji latami obrotowymi spółki. Rezultat liczenia latami obrotowymi pełnienia funkcji (jak również latami kalendarzowymi) nie powoduje tak dużych rozbieżności czasowych, tzn. przedłużania kadencji o rok, a nawet dłużej, nie mówiąc o okresach, które w ogóle nie są brane pod uwagę ${ }^{28}$.

\section{Obliczanie kadencji członków zarządu spółki z o.o.}

W praktyce obliczanie długości kadencji oraz czasu trwania mandatu może budzić wiele trudności ${ }^{29}$. Wiele rozbieżności interpretacyjnych wywołuje art. $202 \S$ 2 ksh., na gruncie którego zarysowują się dwa dominujące stanowiska. Zgodnie z pierwszym stanowiskiem - okres kadencji nie jest liczony według pełnych lat obrotowych, co w konsekwencji prowadzi do liczenia kadencji od dnia powołania, przy czym ostatni rok urzędowania członka zarządu musi być pełnym rokiem obrotowym. Przykładowo mandat członka zarządu powołanego na trzyletnią kadencję w czerwcu 2006 r. wygaśnie najpóźniej w czerwcu 2009 r., z dniem odbycia zgromadzenia wspólników zatwierdzającego sprawozdanie finansowe za rok 2008, który to rok jest ostatnim pełnym rokiem obrotowym urzędowania członka zarządu.

Według drugiego poglądu - kadencję należy liczyć według pełnych lat obrotowych. Stąd powołanie członka zarządu na trzyletnią kadencję oznacza upływ trzech następujących po sobie pełnych lat obrotowych, co powoduje, że okres pełnienia funkcji ulega wydłużeniu (podobnie jak w przypadku określonym w art. $202 \S 1$ ksh.).

Zestawienie art. $202 \S 1 \mathrm{ksh}$. i art. $202 \S 2 \mathrm{ksh}$. pozwala na przyjęcie założenia, że art. $202 \S 2$ ksh. odnosi się do przypadku, gdy zarząd powoływany jest na kadencję wieloletnią, zaś art. $202 \S 1$ ksh. odnosi się do kadencji jednorocznej. Takie

Ibidem, s. 141.

Por. A. Opalski, op. cit., s. 38.

P. Pinior, op. cit., s. 4. 
założenie jest jednak mylące, gdyż dyspozycja art. $202 \S 1$ ksh. wskazuje, że przepis ten znajduje zastosowanie, ,jeżeli umowa nie stanowi inaczej”. Podstawowym zakresem zastosowania art. $202 \S 1 \mathrm{ksh}$. będzie sytuacja, w której umowa milczy w kwestii kadencji członków zarządu. Oznacza to, że jeżeli kadencja nie jest w ogóle w umowie oznaczona, należy przyjąć, że mandat wygasa z dniem odbycia zgromadzenia zatwierdzającego sprawozdanie finansowe za pierwszy pełny rok obrotowy pełnienia funkcji członka zarządu. W związku z powyższym, z art. $202 \S 1 \mathrm{ksh}$. można wyprowadzić wniosek, że w przypadku spółki z ograniczoną odpowiedzialnością ustawodawca przyjął generalną zasadę, iż kadencja jest jednoroczna, co oznacza jeden pełny rok obrotowy pełnienia funkcji przez członka zarządu ${ }^{30}$. Domniemanie rocznej kadencji ustawodawca wprost wyraził w art. $216 \S 1$ ksh., odnośnie do członków rady nadzorczej, zaś kadencja jednoroczna oznacza w tym przypadku jeden pełny rok obrotowy, zgodnie $\mathrm{z}$ art. $218 \S 1 \mathrm{ksh}$. W przypadku zarządu domniemanie jednorocznej kadencji nie zostało wyrażone wprost, jest natomiast wynikiem wykładni obu przepisów dotyczących wygaśnięcia mandatu członka zarządu w trybie art. $202 \S 1$ i $22 \mathrm{ksh}$.

Kolejnym przypadkiem, kiedy art. $202 \S 1 \mathrm{ksh}$. znajduje zastosowanie, jest sytuacja, w której umowa spółki wprowadza jednoroczną kadencję członków zarządu i milczy jednocześnie w kwestii wygaśnięcia mandatu. Artykuł $202 \S 1 \mathrm{ksh}$. stosować należy do kadencji jednorocznej - mimo że przepis ten odnosi się do przypadków, ,gdy umowa nie stanowi inaczej”- gdyż jest to jedyny możliwy do zastosowania przepis, skoro art. $202 \S 2$ ksh. dotyczy kadencji kilkuletniej. W takim przypadku okres kadencji to również okres co najmniej jednego pełnego roku obrotowego. Jeżeli zatem przyjmiemy, że kadencja powinna wynosić - w przypadku braku regulacji w umowie - przynajmniej jeden pełny rok obrotowy, trudno znaleźć uzasadnienie, dlaczego w przypadku kadencji wieloletniej należałoby okres pełnienia funkcji liczyć inaczej niż według pełnych lat obrotowych. Doszlibyśmy bowiem do wniosku, że - na gruncie art. $202 \S 2 \mathrm{ksh}$. - kadencja powinna być liczona w okresach rocznych od dnia powołania, zaś w przypadku określonym w art. $202 \S 1 \mathrm{ksh}$. kadencji nie liczy się od dnia powołania. Wydaje się, że skoro $§ 1$ art. $202 \mathrm{ksh}$. wprowadza zasadę obliczania kadencji wg pełnych lat obrotowych, to konsekwentnie następujący po nim $\S 2$ art. $202 \mathrm{ksh}$. tę zasadę kontynuuje. Trzeba wskazać, że z treści art. $202 \S 2$ ksh. nie wynika, aby kadencji nie liczyć wg pełnych lat obrotowych. Ustawodawca stanowi w art. $202 \S 2 \mathrm{ksh}$. tylko, że mandat wygasa $\mathrm{z}$ dniem odbycia zgromadzenia zatwierdzającego sprawozdanie za ostatni pełny rok obrotowy pełnienia funkcji, gdyż trudno byłoby inaczej ująć zasadę kadencyjności według pełnych lat obrotowych, skoro wspólnicy mają dowolność w określeniu długości kadencji mentarz, t. II, Warszawa 2002, s. 369; A. Kidyba, Spółka z ograniczoną odpowiedzialnością - Komentarz, Warszawa 2005, s. 461. 
w umowie. Jeżeli zatem kadencja jest trzyletnia, to mandat wygasa $\mathrm{z}$ dniem odbycia zgromadzenia zatwierdzającego sprawozdanie finansowe za ostatni, czyli trzeci pełny rok obrotowy ${ }^{31}$.

Przyjęcie stanowiska pierwszego powoduje, że kadencja jednoroczna liczona, zgodnie z art. $202 \S 1$ ksh., pokrywa się z kadencją dwuletnią liczoną zgodnie z art. $202 \S 2$ ksh., co sugerowałoby niekonsekwencję ustawodawcy przy obliczaniu okresu pełnienia funkcji przez członków zarządu. Przykładowo, mandat członka zarządu powołanego na roczną kadencję 1 czerwca 2008 r. wygasa w roku 2010, z dniem odbycia zgromadzenia zatwierdzającego sprawozdanie za rok 2009, który jest w tym przypadku pierwszym pełnym rokiem obrotowym pełnienia funkcji. Z kolei mandat członka zarządu powołanego 1 czerwca 2007 r. na dwuletnią kadencję też wygasa w 2009 r., jeżeli liczymy okres dwóch lat od dnia powołania, zaś rok 2008 jest w tym przypadku ostatnim pełnym rokiem obrotowym pełnienia funkcji. Natomiast przyjęcie we wskazanym przykładzie, że kadencję liczy się wg pełnych lat obrotowych, powoduje, że mandat członka zarządu powołanego na dwuletnią kadencję wygasa w roku 2010. Drugi sposób obliczania kadencji daje już różnicę pomiędzy kadencją jednoroczną a kadencją dwuletnią, co niewątpliwie jest rozwiązaniem logicznym i spójnym. Jednakże rozumując odmiennie, jeżeli umowa spółki nie stanowi inaczej, przykładowo wskazać należy, iż mandaty członków zarządu powołanych 1 czerwca 2007 r. na trzyletnią kadencję wygasną z powodu upływu kadencji już z dniem odbycia zgromadzenia wspólników zatwierdzającego sprawozdanie finansowe za 2009 r. (ostatni pełny rok obrotowy), tj. najpóźniej dnia 30 czerwca $2010 \mathrm{r}^{32}$

Należy podkreślić, że brak jest argumentów przemawiających za tym, aby kadencję jednoroczną liczyć według pełnych lat obrotowych, a już kadencję dwuletnią (kilkuletnią) od dnia powołania. Wykładnia literalna nie daje tutaj satysfakcjonujących wyników. Z kolei wykładnia systemowa art. 202 § 1 i 2, a także art. 218 § 1 i 2 W zw. z art. $216 \S 1$ ksh. umożliwia przyjęcie jednolitego sposobu obliczania kadencji, tj. według pełnych lat obrotowych. Natomiast zastosowanie wykładni celowościowej może prowadzić do odmiennych wniosków. Skoro wspólnicy decydują się na powierzenie uprawnień do zarządzania spółką konkretnym osobom na określony czas liczony w latach kalendarzowych, to sposób liczenia kadencji w latach obrotowych, który prowadzi wprost do wydłużenia czasu sprawowania funkcji w zarządzie spółki, z zasady nie jest zbieżny z ich zamiarem. Jednakże, zdaniem większości przedstawicieli doktryny, obliczanie kadencji wg pełnych lat obrotowych jest ze wszech miar słuszne i odpowiada praktyce obrotu, gdyż zwyczajne zgromadzenie wspólników zatwierdza sprawozdanie z działalności zarządu za cały rok obroto-

32 R.L. Kwaśnicki (red.), Spółka z ograniczoną..., op. cit., s. 280. 
wy oraz przyjmuje sprawozdanie finansowe za ten rok obrotowy ${ }^{33}$. Wtedy następuje udzielenie absolutorium członkom władz spółki, gdyż z reguły to rok obrotowy jest okresem, za który rozliczani są członkowie władz, a zatem zmiana menedżerów w trakcie roku obrotowego jest niekorzystna z punktu widzenia działalności spólki, prowadzonej przez spółkę polityki gospodarczej, a w szczególności - polityki finansowej, chyba że zachodzą powody uzasadniające wcześniejsze odwołanie członków zarząqu ${ }^{34}$.

Żaden z komentatorów przepisów ksh., jak również żaden z autorów rozważających kwestie praktycznego stosowania przepisów art. $202 \S 1 \mathrm{ksh}$. i $202 \S 2 \mathrm{ksh}$. nie odnosi się do sytuacji faktycznej, w której to kadencja rozpoczyna się przykładowo w dniu 1 grudnia, tj. po dacie, do której musi odbyć się zwyczajne zgromadzenie wspólników zatwierdzające sprawozdanie finansowe za poprzedni rok obrotowy. Jeżeli przyjmiemy, że trzyletnia kadencja zarządu rozpoczęła się 1 grudnia 2006 r., to będzie trwała do dnia 1 grudnia 2009 r. Biorąc pod uwagę treść art. $202 \S$ 1 oraz $\S 2 \mathrm{ksh}$. mandaty członków zarządu wygasną z chwilą odbycia zgromadzenia za ostatni pełny rok obrotowy pełnienia funkcji. Wobec przytaczanych wyżej koncepcji liczenia długości kadencji w latach obrotowych lub latach kalendarzowych, nie ma możliwości udzielenia jednoznacznej odpowiedzi na pytanie, czy mandaty wygasną z chwilą udzielenia absolutorium za 2008 r. (najpóźniej do dnia 30 czerwca 2009 r.), czy też z chwilą udzielenia absolutorium za 2009 r. (najpóźniej do dnia 30 czerwca 2010 r.). Przyjęcie pierwszego rozwiązania powoduje, że kadencja ulega skróceniu, natomiast przyjęcie drugiego skutkuje wydłużeniem kadencji, co - jak się wydaje - może implikować powstanie wielu ryzyk prawnych związanych z reprezentacją spółki ${ }^{35}$.

\section{Niezatwierdzenie sprawozdania finansowego a wygaśnięcie mandatu}

Przepisy art. $202 \S 1$ ksh. i art. $202 \S 2$ ksh. wprowadzają zasadę, zgodnie z którą wygaśnięcie mandatu członka zarządu następuje z dniem odbycia zgromadzenia wspólników zatwierdzającego sprawozdanie finansowe za rok obrotowy. W związ$\mathrm{ku} \mathrm{z}$ tą regulacją pojawiły się w doktrynie wątpliwości dotyczące kwestii wygaśnięcia mandatu w przypadku niezatwierdzenia sprawozdania finansowego, w przypadku niepodjęcia jakiejkolwiek uchwały w tym przedmiocie oraz w sytuacji, gdy zgromadzenie, w którego porządku obrad zapowiedziano podjęcie uchwały zatwierdzającej sprawozdanie finansowe, nie odbyło się. Bezspornym pozostaje, że man-

Taka argumentację prezentuje Minister Skarbu Państwa RP w wyjaśnieniach w sprawie sposobu liczenia kadencji członków organów spółek kapitałowych, DP-MP-079-172/04, MSP/DP/6957/04 pkt 4.1.3., s. 3. 
dat członka zarządu wygasa w przypadku zatwierdzenia sprawozdania finansowego, jak i to, że mandat nie wygasa w przypadku nieodbycia się zgromadzenia, które miało zatwierdzić sprawozdanie finansowe. Rozbieżności powstają gdy zgromadzenie wspólników odbywa się, jednakże w sprawie zatwierdzenia sprawozdania zapada uchwała negatywna lub też gdy to zgromadzenie nie podejmuje jakiejkolwiek uchwały w przedmiocie zatwierdzenia sprawozdania finansowego.

Część przedstawicieli doktryny ${ }^{36}$ stoi na stanowisku, że niezbędną przesłanką wygaśnięcia mandatu członka zarządu spółki jest zatwierdzenie sprawozdania finansowego za poprzedni rok obrotowy, czyli podjęcie uchwały w tym przedmiocie wymaganą większością głosów. Stanowisko to oparte jest m.in. na założeniu, że przepisy ksh. wskazują jednoznacznie na zgromadzenie „zatwierdzające” sprawozdanie finansowe, a nie jedynie „rozpatrujące” sprawozdanie finansowe, przy czym uzasadnienie rozróżnienia tych dwóch pojęć wywodzi się z analizy art. 228 pkt 1 ksh., art. $231 \S 2$ pkt 1 ksh., art. 393 pkt 1 ksh. oraz art. $395 \S 2$ pkt 1 ksh. Powołuje się także argumenty wykładni funkcjonalnej i językowej.

Druga grupa autorów ${ }^{37}$ zajmuje odmiennie stanowisko, przyjmując, że do wygaśnięcia mandatu nie jest konieczne zatwierdzenie sprawozdania finansowego. Argumentem przemawiającym za tym stanowiskiem jest także brzmienie art. $202 \S 1$ i $\S 2 \mathrm{ksh}$. oraz art. $369 \S 4$ ksh., jednakże w tym przypadku podkreśla się, że podstawowe znaczenie ma „odbycie” zgromadzenia zatwierdzającego sprawozdanie, bez względu na to, czy sprawozdanie zostało ostatecznie zatwierdzone. Do wygaśnięcia mandatu nie jest konieczne zatwierdzenie sprawozdania finansowego, jednakże konieczne jest podjęcie jakiejkolwiek uchwały w tym przedmiocie: albo pozytywnej (zatwierdzającej), albo negatywnej (niezatwierdzenie sprawozdania na skutek nieuzyskania wymaganej większości głosów). Samo zaś odbycie się zgromadzenia bez podjęcia uchwały, nawet jeśli była zapowiedziana w porządku obrad, nie jest wystarczające do uznania, że mandaty członków zarządu wygasły.

Zdaniem autorów niniejszego opracowania, w tej kwestii należy zgodzić się $\mathrm{z}$ drugim z prezentowanych poglądów. Trzeba przede wszystkim podkreślić, że do wygaśnięcia mandatu konieczne jest odbycie zgromadzenia zatwierdzającego sprawozdanie finansowe. Jest to zgromadzenie, w którego porządku obrad zapowiedziano zatwierdzenie sprawozdania oraz głosowano w tej sprawie. Odbycie głosowania co do zatwierdzenia sprawozdania finansowego jest konieczne, gdyż sama dyskusja w tym przedmiocie jest jedynie „rozpatrywaniem” sprawozdania, a nie jego „zatwierdzaniem". Natomiast do wygaśnięcia mandatu nie jest konieczne zatwierdzenie sprawozdania finansowego, a jedynie podjęcie uchwały w tym przedmiocie. Oznacza to, że mandat wygasa w przypadku, gdy zgromadzenie podejmie uchwa- 
łę zatwierdzającą sprawozdanie finansowe, jak również gdy zgromadzenie podejmie uchwałę negatywna, tzn. nie zatwierdzi sprawozdania finansowego. Wynika to z faktu, iż w spółkach kapitałowych nie zawsze musi nastapić zatwierdzenie sprawozdania finansowego przez wspólników. Jeżeli bowiem istnieją uzasadnione wątpliwości co do treści sprawozdania, a wspólnicy oddadzą głosy „przeciw”, wówczas nie dojdzie do zatwierdzenia sprawozdania finansowego, ale niewątpliwie będzie to zgromadzenie ,zatwierdzające" sprawozdanie finansowe. Przyjęcie odmiennego stanowiska (stwierdzającego, że konieczne jest zatwierdzenie sprawozdania finansowego) prowadziłoby do nieuzasadnionego przedłużania mandatu członkom zarządu, mimo że w większości wypadków wątpliwości wspólników co do zatwierdzenia sprawozdania finansowego są efektem działań tych właśnie osób.

Trzeba ponadto podkreślić, że ksh. wskazuje w niektórych przepisach jednoznacznie, że określony skutek wiązać należy z zatwierdzeniem sprawozdania finansowego (por. art. $195 \S 1 \mathrm{ksh}$. czy art. $349 \S 2 \mathrm{ksh}$.). W przypadku wygaśnięcia mandatu przepis nie jest tak jednoznaczny. Trzeba zatem uznać, że do wygaśnięcia mandatu konieczne jest odbycie zgromadzenia wspólników (walnego zgromadzenia) zatwierdzającego sprawozdanie finansowe, tj. podejmującego uchwałę w tym przedmiocie, bez względu na wynik głosowania.

\section{Dopuszczalność powołania członków zarządu spółki z o.o. na czas nieoznaczony}

Regułą w spółkach kapitałowych jest kadencyjność organów. Przede wszystkim dotyczy to organów nadzorujących spółkę z ograniczoną odpowiedzialnością, co wynika bezpośrednio z treści przepisu art. $216 \S 1 \mathrm{ksh}$. Kadencja powinna zatem zostać określona w umowie spółki, przy czym w przypadku spółki akcyjnej kadencja zarządu i rady nadzorczej nie może przekraczać 5 lat (art. $369 \S 1$ ksh. oraz art. $386 \S 1 \mathrm{ksh}$.), natomiast w przypadku rady nadzorczej, a także komisji rewizyjnej, w spółce z ograniczoną odpowiedzialnością przyjęto zasadę, że członków tych organów powołuje się na rok, jeżeli umowa nie stanowi inaczej.

Natomiast w przypadku zarządu spółki z ograniczoną odpowiedzialnością brak jest regulacji wskazującej na długość kadencji. Z treści przepisu art. $202 \S 2$ ksh. wynika tylko, że członek zarządu może być powołany na okres dłuższy niż rok. Powstaje zatem pytanie, czy dopuszczalne jest powołanie członków zarządu spółki z o. o. na czas nieoznaczony, a jeżeli uznać to za dopuszczalne, to czy brak jakichkolwiek postanowień umowy w tym przedmiocie oznacza, że członków zarządu powołano na czas nieoznaczony. Należy rozstrzygnąć, czy brak jakichkolwiek postanowień umowy spółki dotyczących kadencji członków zarządu umożliwia przyjęcie poglądu, że kadencja członków zarządu spółki z ograniczoną odpowiedzialnością 
jest nieoznaczona. Również w tym przypadku nie można pominąć kwestii wygaśnięcia mandatu, co jest nierozerwalnie związane z problemem czasu pełnienia funkcji. Jak już wcześniej wskazano, w takim przypadku znajduje zastosowanie art. 202 $\S 1$ ksh., który przewiduje wygaśnięcie mandatu z dniem odbycia zgromadzenia wspólników zatwierdzającego sprawozdanie finansowe za pierwszy pełny rok obrotowy pełnienia funkcji. Zatem w przypadku braku postanowień umownych nie mamy do czynienia z nieoznaczoną kadencją, a z kadencją jednoroczną ${ }^{38}$.

Należy także zastanowić się nad tym, czy dopuszczalne jest postanowienie umowy spółki z o.o., które przewiduje powoływanie członków zarządu na czas nieoznaczony. Porównując regulację przepisów dotyczących powoływania członków władz spółek kapitałowych, należy dostrzec, że jedynie w przypadku zarządu spółki z ograniczoną odpowiedzialnością przepisy milczą co do długości kadencji członków zarządu. Jak już wcześniej wskazano, w pozostałych przypadkach mamy do czynienia z kadencyjnością członków organów spółki, zaś w przypadku członków zarządu i rady nadzorczej spółki akcyjnej kadencję wyraźnie ograniczono do maksimum 5 lat. Wydaje się zatem, że skoro ustawodawca nie ogranicza w przypadku zarządu spółki z o.o. długości kadencji (co więcej - pozostawia kwestie dotyczące kadencji swobodnemu uznaniu wspólników w umowie), to brak jest ograniczeń co do treści postanowień umownych ${ }^{39}$. Należy zatem uznać, że dopuszczalne jest powoływanie członków zarządu spółki z o.o. na czas nieoznaczony, jednakże musiałoby to wprost wynikać z postanowień umowy spółki. W przypadku powołania członka zarządu na czas nieoznaczony jego mandat wygasa z dniem odwołania, rezygnacji, śmierci czy innego zdarzenia uniemożliwiającego pełnie funkcji członka zarządu.

\section{Wnioski}

Każda z przedstawionych koncepcji liczenia kadencji członków zarządu rodzi pewne wątpliwości. Wynikają one z konieczności przyjęcia, że mandaty wygasają, stosownie do woli ustawodawcy, z dniem odbycia zgromadzenia wspólników zatwierdzającego sprawozdanie finansowe oraz założenia, że jest to data zakończenia pełnienia funkcji. W żadnym wypadku nie da się określić w umowie spółki długości kadencji w pełnych latach (czy to kalendarzowych, czy to obrotowych) tak, aby końcowa data kadencji zbiegała się z dniem wygaśnięcia mandatu, przy założeniu, że zostanie zastosowany przepis art. $202 \mathrm{ksh}$. wprost. Jeżeli te daty powinny być zbieżne, konieczne są dodatkowe zastrzeżenia wynikające z przyjętej wykład-

\footnotetext{
38 Tak, A. Szumański, (w:), S. Sołtysiński, A. Szajkowski, A. Szumański, J. Szwaja, Kodeks spółek handlowych..., op. cit., s. 371, jednakże autor nie analizuje sytuacji polegającej na zawarciu w umowie spółki klauzuli o powołaniu członków zarządu na czas nieoznaczony, ograniczając uwagi do sytuacji braku jakichkolwiek postanowień umowy co do pełnienia funkcji członka zarządu spółki.
}

A. Kidyba, Spółka z ograniczoną..., op. cit., s. 461. 
ni art. 202 ksh. Może być to zastrzeżenie wskazujące, że obliczając kadencje,, należy zawsze ją wydłużyć do daty wygaśnięcia mandatu, albo że mimo upływu kadencji, członek dalej wykonuje swoją funkcję do czasu wygaśnięcia mandatu. Podkreślić należy, że dotychczas w literaturze kwestia ta nie została dokładnie sprecyzowana. Zwykle bez przywiązywania wagi do konsekwencji używa się zamiennie sformułowań o wydłużeniu kadencji lub o dalszym pełnieniu funkcji mimo upływu kadencji, co zdaniem autorów nie jest tożsame.

Sposób liczenia kadencji powinien być jednolity. De lege lata trudno o spójną wykładnię art. 202 ksh. Różne koncepcje w tym względzie rodzą niebezpieczeństwo podważania ważności czynności dokonywanych przez członków zarządu po upływie terminu, który według jednej z koncepcji oznacza koniec pełnienia funkcji, gdy inni przyjmują, że termin ten jeszcze nie nastapił. Wobec braku jednolitego stanowiska doktryny i jednolitej linii orzeczniczej procesowe rozstrzygnięcie ewentualnego sporu jest trudne do przewidzenia.

Dyspozytywny charakter art. $202 \S 1$ ksh. pozwala uniknąć rozbieżności interpretacyjnych przez sprecyzowanie w umowie kwestii spornych. W interesie spółki, jej wspólników oraz osób pełniących funkcje członków zarządu leży niebudzące wattpliwości rozwiązanie tej kwestii. Wydaje się, że należy pozostawić ustawowo określoną zasadę wygasania mandatu $\mathrm{z}$ dniem odbycia zgromadzenia zatwierdzającego sprawozdanie finansowe. Natomiast w umowie można rozstrzygnąć nie tylko długość kadencji poprzez wyznaczenie jej w latach (np. 3 letnia kadencja), ale wyraźnie stwierdzić, że kończy się ona w dniu, którym wygasa mandat, a następuje to na zgromadzeniu zatwierdzającym sprawozdanie za ostatni pełny rok obrotowy danej kadencji.

Innym rozwiązaniem jest przyjęcie w umowie, iż kadencję liczy się latami kalendarzowymi (data do daty, tak jak nakazuje art. $112 \mathrm{kc}$.), co powoduje, że wraz $\mathrm{z}$ upływem kadencji wygasa mandat. Obliguje to do powołania w tak ustalonym czasie członków zarządu w miejsce tych, których kadencja upłynęła i wygasł mandat. Jest to rozwiązanie pozostające w pewnej opozycji do modelu kodeksowego, ale budzi mniej pytań, na które odpowiadać można różnie, w zależności od przyjętej koncepcji. Można tu dostrzec wyraźną analogię do przepisu art. $202 \S 4$ ksh., który określa niezwiązany z dniem odbycia zgromadzenia zatwierdzającego sprawozdanie finansowe moment wygasania mandatów na wypadek śmierci, rezygnacji lub odwołania ze składu zarządu. Powiązanie wygasania mandatów z dniem odbycia zgromadzenia zatwierdzającego sprawozdanie finansowe ma swoje uzasadnienie $\mathrm{z}$ uwagi na rytm funkcjonowania spółki, ale nie jest bezwzględnie konieczne. Zaletą przedstawionego rozwiązania, obok niebudzącego wątpliwości sposobu liczenia kadencji, jest to, że pozwala wspólnikom (czy innym osobom mającym odpowiednią kompetencję) precyzyjnie (co do dnia) wyznaczyć czas pełnienia funkcji w zarzą- 
dzie wskazanej osobie (osobom) zgodnie z wolą wspólników wyrażoną w umowie spółki. Niebezpieczeństwo pozostawienia spółki bez zarządu jest niewielkie. Skoro wiadomo od początku, kiedy dokładnie kończy się kadencja i wygasa mandat, można przygotować czynności zmierzające do powołania zarządu nowej kadencji z odpowiednim wyprzedzeniem.

Zdaniem autorów, wnioski de lege ferenda co do sztywnego wyznaczenia w przepisach kodeksu momentu wygaśnięcia mandatu wraz z upływem kadencji można byłoby uznać za zbyt daleko idące. Mogłoby to naruszyć autonomię woli wspólników. Dyspozytywna konstrukcja większości przepisów ksh. dotyczących spółki z ograniczoną odpowiedzialnością, a w szczególności liczenia długości kadencji i wygaśnięcia mandatu, pozwala wspólnikom na swobodne kształtowanie wewnętrznego stosunku spółki pomiędzy nimi. Możliwość swobodnego regulowania omawianych kwestii w umowie spółki pozwala praktycznie i skutecznie realizować nadzór właścicielski nad spółką. Wątpliwości co do liczenia długości kadencji mogą zostać wyeliminowane, gdy wspólnicy, korzystając z możliwości, jakie daje im dyspozytywny charakter przepisów, doprecyzują w umowie założycielskiej zasady dotyczące czasu pełnienia funkcji w zarządzie ich spółki. 


\title{
THE TERM OF OFFICE OF BOARD OF A LIMITED LIABILITY COMPANY
}

\author{
SUMMARY
}

The term and the concept that function on the grounds of the Commercial Companies Code are the basis for functioning of bodies within the companies - a limited liability company and a joint stock company. In practice, to calculate the length of the term and the duration of the mandate raises many difficulties, depending on position. According to the first standpoint - the term of office is not counted by the full financial years, which consequently leads to counting the term from the date of appointment, with the last year of office of a member of the board must be a full financial year. According to the second view - the term must be counted by the full financial years. Hence the appointment of the board member for three years, means the passage of three consecutive full financial years, which makes that the period of the term of office is extended. A comprehensive analysis of all the issues that make up the problem of timing to hold office on the board of a limited liability company is not possible in this study. However, the authors set themselves the target of explanation only those issues that will propose a coherent concept of counting time within the board of a limited liability company, which offers to apply in practice. 